\title{
Characterization of photoautotrophic picoplankton assemblages in turbid, alkaline lakes of the Carpathian Basin (Central Europe)
}

\author{
Tamás FELFÖLDI*, Boglárka SOMOGYI ${ }^{1)}$, Károly MÁRIALIGETI and Lajos VÖRÖS ${ }^{1)}$ \\ Department of Microbiology, Eötvös Loránd University, Pázmány Péter s. 1/c., H-1117 Budapest, Hungary \\ ${ }^{1)}$ Balaton Limnological Research Institute of the HAS, Klebelsberg Kuno u. 3., H-8237 Tihany, Hungary \\ *e-mail corresponding author: tamas.felfoldi@gmail.com
}

\begin{abstract}
The photoautotrophic picoplankton (PPP) of ten shallow, hyposaline soda lakes located in three different geographical regions in the Carpathian Basin (Central Europe) was characterized. These lakes, which frequently dry out completely, are extremely rich in PPP. Epifluorescence microscopy was applied to determine picocyanobacterial and picoeukaryotic cell abundance and PCR-based molecular techniques (denaturing gradient gel electrophoresis and cloning with phylospecies delineation) to identify the members of PPP. Most of these lakes were eu- and hypertrophic with varying contribution of picocyanobacteria to the total PPP cell number. We found an unusually high PPP abundance with peaks of $8.16 \times 10^{6}$ cells $\mathrm{mL}^{-1}$ for picoeukaryotes and $1.78 \times 10^{7}$ cells $\mathrm{mL}^{-1}$ for picocyanobacteria. The majority of the retrieved PPP sequences belonged to picocyanobacteria (nonmarine Synechococcus/ Cyanobium), while others showed similarity to eukaryotic algal plastids (close to Trebouxiophycean isolates). Molecular analysis revealed significant genetic diversity in the PPP fraction of these lakes and showed that the closest relatives of our picocyanobacterial clones were recovered from different habitats, indicating seemingly no correlation between the 'saline' ecotypes and their phylogenetic position. Our results also confirmed that PPP might exploit different aquatic ecosystems and be successful even in the case of abrupt changes of environmental parameters (in our case, salinity). According to our knowledge, this is the first survey focusing on the identification of the PPP community members in turbid and alkaline lakes with extraordinarily high picoplankton productivity.
\end{abstract}

Key words: soda lake, photoautotrophic picoplankton, epifluorescence microscopy, PCR-based molecular techniques

\section{INTRODUCTION}

Shallow, turbid soda lakes are very characteristic of the Carpathian Basin. These are mostly intermittent shallow, alkaline pans that frequently dry out completely by the end of the summer. Their salinity varies from hypo- to mesosaline ranges in accordance with the season and water level (Schmidt \& Fehér 2001; Schmidt 2003). Algological investigations of Hungarian soda lakes and Lake Fertő (Neusiedlersee) were intensive in the last century, which resulted in an exhaustive long list of species with limited information about pico-sized $(<2 \mu \mathrm{m})$ algae (Dokulil \& Padisák 1994; Padisák \& Dokulil 1994; Schmidt \& Fehér 2001). Recent studies of the photoautotrophic picoplankton (PPP) of these water bodies showed that red-fluorescent coccoid $1 \mu \mathrm{m}$ sized unicellular cyanobacteria and eukaryotic algae dominated (74-100\%) the phytoplankton (Vörös \& V.Balogh 2003; Vörös et al. 2005).

According to the well-documented relationship in marine and freshwaters, the contribution of PPP to the total phytoplankton biomass decreases with the increase of the trophic state (Stockner 1988; Søndergaard 1991; Stockner \& Shortreed 1991; Agawin et al. 2000; Bell \& Kalff 2001; Callieri 2008), however the investigated hypertrophic Hungarian turbid pans do not follow this trend (Vörös \& V.-Balogh 2003; Vörös et al. 2005).
Furthermore, the latest findings indicated that the soda lakes of the Carpathian Basin had the highest PPP abundance (both for picocyanobacteria and picoeukaryotic algae) ever reported in aquatic environments (Carrick \& Schelske 1997; Vörös et al. 2005; Sarmento et al. 2008; Vörös et al. 2008; Somogyi et al. 2009).

Members of PPP can be enumerated by epifluorescence microscopy (e.g., Johnson \& Sieburth 1979; Waterbury et al. 1979) or flow cytometry (e.g., Chisholm et al. 1988; Li \& Wood 1988; Olson et al. 1990), but the identification of these bacterium-sized algae is often very problematic because of their small cell size and the limited number of distinct morphological characters. In many cases, these problems are associated with the known difficulties of cultivation (Ernst 1991; Rippka et al. 2000; Ernst et al. 2003), hence the species composition of picoplankton communities can mainly be defined with molecular methods. The application of culture independent techniques, such as cloning and sequence-based phylospecies identification, fluorescent in situ hybridization (FISH) and denaturing gradient gel electrophoresis (DGGE) provided new facilities in environmental microbiology, including the examination of aquatic microbial communities (reviewed by Dorigo et al. 2005). On the other hand, methods based on genetic characterization revised the taxonomy and systematics of picocyanobacteria (Honda et al. 1999; Turner et al. 1999; Robertson et al. 2001) and picoeukaryotic algae 


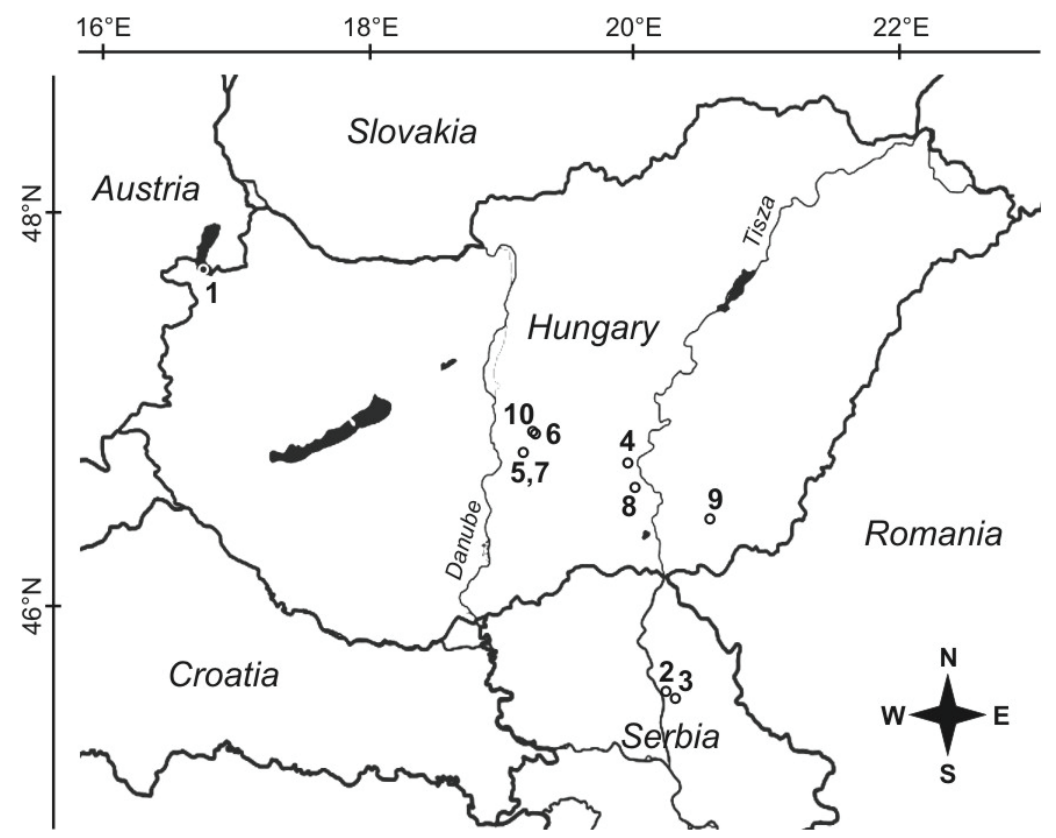

Fig. 1. Geographical location of sampling sites in the Carpathian Basin. 1 Lake Fertő (Neusiedlersee), 2 Lake Slano Kopovo, 3 Lake Rusanda, 4 Lake Kis-Sós, 5 Kastély Pond, 6 Kelemen-szék Pan, 7 Böddi-szék Pan, 8 Büdös-szék Pan, 9 Lake Fehér, 10 Zab-szék Pan.

(Huss et al. 1999; Henley et al. 2004), and also revealed the presence of a significant uncultured fraction (Moonvan der Staay et al. 2001; Fuller et al. 2006; Ivanikova et al. 2007). The relatively large number of available small subunit ribosomal RNA gene sequences (SSU or 16S rDNA) for cyanobacteria and eukaryotic plastids (Cole et al. 2003) provides a considerable database for oxygenic phototrophs in the course of DNA-based community diversity investigations.

In this study, we examined the PPP community inhabiting the extremely turbid and productive lakes of the Carpathian Basin with the application of epifluorescent enumeration and molecular characterization.

\section{MATERIALS AND METHODS}

\subsection{Study sites and sampling}

Samples were collected between 2003 and 2005 from ten turbid, shallow water bodies of the Carpathian Basin from three different geographical regions: the Fertö-Hanság Region (Lake Fertö), the Vojvodina Region (Lake Rusanda and Slano Kopovo) and the Kiskunság Region (Fig. 1, Tabs 1 and 2).

Lake Fertő (Neusiedlersee) is a large, turbid, shallow lake on the Austrian-Hungarian border. The reed-zone divides the open water into several parts: there are large, open water areas and small, isolated inner ponds. Our sample was taken from the turbid, white-colored openwater area in the Hungarian part of the lake. The lake is characterized as meso-eutrophic (Dokulil \& Padisák 1994), and chlorophyll- $a$ maximum usually does not exceed $25 \mu \mathrm{g} \mathrm{L}^{-1}$.
Kastély Pond is a man-made shallow pond in the Kiskunság Region of South Hungary, which does not have typical turbid, white-colored water due to its small surface area and the relatively large water depth. The other investigated lakes are typical turbid, intermittent, shallow pans with white-colored water and very low Secchi-disk (SD) transparency $(1-5 \mathrm{~cm})$, due to the high concentration of suspended solids and dissolved organic substances (Vörös et al. 2006). The water is rich in $\mathrm{Na}^{+}$, $\mathrm{HCO}_{3}{ }^{-}, \mathrm{SO}_{4}{ }^{2-}$ and $\mathrm{Cl}^{-}$ions with $\mathrm{pH}$ values between 9 and 10 (Tab. 1). Most lakes of the Kiskunság Region could be characterized as hypertrophic water bodies (Vörös \& V.-Balogh 2003; Vörös et al. 2005; Vörös et al. 2008; Somogyi et al. 2009). The trophic state of three lakes (Lake Slano Kopovo, Lake Rusanda and Lake Kis-Sós) could not be determined from our single measurement.

Temperature, $\mathrm{pH}$ and conductivity values of each sample were determined with a MultiLine P4 meter (WTW, Weilheim, Germany).

Surface-water samples were collected for algological and molecular characterization, and the samples were transferred to the laboratory without preservation in a thermo box in dark conditions. Sample processing started within 3-6 hours after sampling.

\subsection{Phytoplankton biomass and PPP composition}

Chlorophyll- $a$ concentration of the phytoplankton was determined from fresh samples. Aliquots (10-100 $\mathrm{mL}$ depending on algal biomass) were filtered through GF-5 glass fiber filters. Chlorophyll- $a$ was extracted with hot methanol $\left(64.7^{\circ} \mathrm{C}, 1 \mathrm{~min}\right)$ and the concentra- 
Tab. 1. Major characteristic features of the sampled soda lakes in the Carpathian Basin (based on Vörös et al. 2006). Lake numbers refer to codes on figure $1 . *$ : based on the values measured on sampling dates.

\begin{tabular}{|c|c|c|c|c|c|c|c|c|c|}
\hline \multirow[t]{2}{*}{$\begin{array}{l}\text { Region } \\
\text { (Country) }\end{array}$} & \multirow[t]{2}{*}{ Lake } & \multicolumn{2}{|c|}{$\begin{array}{c}\text { Geographical } \\
\text { coordinates }\end{array}$} & \multirow{2}{*}{$\begin{array}{c}\text { Surface } \\
\text { area } \\
\left(\mathrm{km}^{2}\right)\end{array}$} & \multirow{2}{*}{$\begin{array}{l}\text { Water } \\
\text { depth } \\
(\mathrm{cm})\end{array}$} & \multirow{2}{*}{$\begin{array}{c}\mathrm{SD} \\
\text { transparency } \\
(\mathrm{cm})\end{array}$} & \multirow[t]{2}{*}{$\mathrm{pH}$} & \multirow[t]{2}{*}{$\begin{array}{l}\text { Dominant } \\
\text { cation }\end{array}$} & \multirow[t]{2}{*}{$\begin{array}{l}\text { Dominant } \\
\text { anion(s) }\end{array}$} \\
\hline & & $\mathrm{N}$ & $\mathrm{E}$ & & & & & & \\
\hline $\begin{array}{l}\text { Fertő-Hanság } \\
\text { (Hungary-Austria) }\end{array}$ & 1 Lake Fertő (Neusiedlersee) & $47^{\circ} 40^{\prime}$ & $16^{\circ} 45^{\prime}$ & 300 & $100-120$ & $5-30$ & $9.0-9.3$ & $\mathrm{Na}^{+}$ & $\mathrm{HCO}_{3}>\mathrm{SO}_{4}{ }^{2-}$ \\
\hline Vojvodina (Serbia) & $\begin{array}{l}2 \text { Lake Slano Kopovo* } \\
3 \text { Lake Rusanda* }\end{array}$ & $\begin{array}{l}45^{\circ} 37^{\prime} \\
45^{\circ} 31^{\prime}\end{array}$ & $\begin{array}{l}20^{\circ} 12^{\prime} \\
20^{\circ} 17^{\prime}\end{array}$ & $\begin{array}{l}1.04 \\
1.70\end{array}$ & $\begin{array}{l}30 \\
20\end{array}$ & $\begin{array}{l}2 \\
4\end{array}$ & $\begin{array}{l}8.9 \\
9.3\end{array}$ & $\begin{array}{l}\mathrm{Na}^{+} \\
\mathrm{Na}^{+}\end{array}$ & $\begin{array}{l}\mathrm{Cl}^{-}>\mathrm{SO}_{4}{ }^{2-}>\mathrm{HCO}_{3}{ }^{-} \\
\mathrm{SO}_{4}{ }^{2-}>\mathrm{HCO}_{3}>\mathrm{Cl}^{-}\end{array}$ \\
\hline Kiskunság (Hungary) & \begin{tabular}{|l}
4 Lake Kis-Sós* \\
5 Kastély pond \\
6 Kelemen-szék pan \\
7 Böddi-szék pan \\
8 Büdös-szék pan \\
9 Lake Fehér \\
10 Zab-szék pan
\end{tabular} & $\begin{array}{l}46^{\circ} 44^{\prime} \\
46^{\circ} 46^{\prime} \\
46^{\circ} 49^{\prime} \\
46^{\circ} 46^{\prime} \\
46^{\circ} 33^{\prime} \\
46^{\circ} 28^{\prime} \\
46^{\circ} 50^{\prime}\end{array}$ & $\begin{array}{l}19^{\circ} 59^{\prime} \\
19^{\circ} 08^{\prime} \\
19^{\circ} 11^{\prime} \\
19^{\circ} 08^{\prime} \\
20^{\circ} 02^{\prime} \\
20^{\circ} 37^{\prime} \\
19^{\circ} 10^{\prime}\end{array}$ & $\begin{array}{l}0.10 \\
0.01 \\
1.20 \\
1.17 \\
0.50 \\
0.70 \\
1.00\end{array}$ & $\begin{array}{c}22 \\
60-100 \\
<50 \\
<50 \\
<50 \\
<50 \\
<50\end{array}$ & $\begin{array}{c}5 \\
17-35 \\
1-5 \\
1-5 \\
1-5 \\
1-5 \\
1-5\end{array}$ & $\begin{array}{c}9.1 \\
9.0-9.9 \\
9.0-9.7 \\
8.8-9.8 \\
9.1-9.7 \\
9.1-9.7 \\
9.1-9.8\end{array}$ & $\begin{array}{l}\mathrm{Na}^{+} \\
\mathrm{Na}^{+} \\
\mathrm{Na}^{+} \\
\mathrm{Na}^{+} \\
\mathrm{Na}^{+} \\
\mathrm{Na}^{+} \\
\mathrm{Na}^{+}\end{array}$ & $\begin{aligned} \mathrm{HCO}_{3}^{-} & \\
\mathrm{HCO}_{3}^{-} & >\mathrm{Cl}^{-} \\
\mathrm{HCO}_{3}^{-} & >\mathrm{Cl}^{-} \\
\mathrm{HCO}_{3}^{-} & >\mathrm{Cl}^{-} \\
\mathrm{HCO}_{3}^{-} & \\
\mathrm{HCO}_{3}^{-} & >\mathrm{Cl}^{-} \\
\mathrm{HCO}_{3} & >\mathrm{Cl}^{-}\end{aligned}$ \\
\hline
\end{tabular}

Tab. 2. List of investigated samples with their phytoplankton biomass and PPP abundance collected from different soda lakes in the Carpathian Basin. *: sample was cloned.

\begin{tabular}{|c|c|c|c|c|c|c|}
\hline Lake & Sampling date & $\begin{array}{c}\text { Temperature } \\
\left({ }^{\circ} \mathrm{C}\right)\end{array}$ & $\begin{array}{l}\text { Conductivity } \\
\left(\mu \mathrm{S} \mathrm{cm}^{-1}\right)\end{array}$ & $\begin{array}{l}\text { Chlorophyll- } a \\
\left(\mu \mathrm{g} \mathrm{L}^{-1}\right)\end{array}$ & $\begin{array}{c}\text { Abundance of } \\
\text { picocyanobacteria } \\
\left(10^{4} \text { cells } \mathrm{mL}^{-1}\right)\end{array}$ & $\begin{array}{l}\text { Abundance of } \\
\text { picoeukaryotes } \\
\left(10^{4} \text { cells } \mathrm{mL}^{-1}\right)\end{array}$ \\
\hline Lake Fertő & 28 Apr 2004 & 16 & 2500 & 31 & 309 & $<0.1$ \\
\hline Lake Slano Kopovo & 23 Apr 2005 & 15 & 3220 & 6.0 & 168 & 3.7 \\
\hline Lake Rusanda & 23 Apr 2005 & 15 & 10400 & 2.0 & 7.3 & 0.5 \\
\hline Lake Kis-Sós & 23 Apr 2005 & 11 & 1845 & 3.0 & 0.1 & 8.6 \\
\hline Kastély Pond & $\begin{array}{l}16 \text { Mar } 2004 \\
4 \text { Jul } 2004 \\
17 \text { Oct } 2004\end{array}$ & $\begin{array}{l}11 \\
28 \\
10\end{array}$ & $\begin{array}{l}5390 \\
5220 \\
5580\end{array}$ & $\begin{array}{l}68 \\
32 \\
94\end{array}$ & $\begin{array}{l}466 \\
356 \\
760\end{array}$ & $\begin{array}{l}47 \\
<0.1 \\
<0.1\end{array}$ \\
\hline Kelemen-szék Pan & $\begin{array}{l}1 \text { May } 2003 \\
17 \text { Oct } 2004 \\
7 \text { Jul } 2005\end{array}$ & $\begin{array}{c}19 \\
9 \\
28\end{array}$ & $\begin{array}{l}4670 \\
7950 \\
6300\end{array}$ & $\begin{array}{l}24 \\
23 \\
7.6\end{array}$ & $\begin{array}{c}399 \\
10 \\
32\end{array}$ & $\begin{array}{c}<0.1 \\
42 \\
12.8\end{array}$ \\
\hline Böddi-szék Pan & $\begin{array}{c}26 \text { Apr } 2004 \\
4 \text { Jul } 2004 \\
3 \text { Sep } 2004 \\
\text { 17 Oct } 2004 \\
23 \text { Apr } 2005 \\
7 \text { Jul } 2005\end{array}$ & $\begin{array}{c}12 \\
30 \\
22 \\
8 \\
16 \\
28\end{array}$ & $\begin{array}{c}4100 \\
9050 \\
14370 \\
16480 \\
6710 \\
9700\end{array}$ & $\begin{array}{c}9.0 \\
81 \\
94 \\
57 \\
120 \\
81\end{array}$ & $\begin{array}{c}0.1 \\
1032 \\
1783 \\
623 \\
213 \\
519\end{array}$ & $\begin{array}{c}33 \\
31 \\
32 \\
107 \\
171 \\
65\end{array}$ \\
\hline Büdös-szék Pan & $\begin{array}{l}3 \text { Sep } 2004 \\
17 \text { Oct } 2004 \\
7 \text { Jul } 2005\end{array}$ & $\begin{array}{l}24 \\
11 \\
29\end{array}$ & $\begin{array}{l}4410 \\
4700 \\
3700\end{array}$ & $\begin{array}{l}44 \\
34 \\
11\end{array}$ & $\begin{array}{c}22.7 \\
107 \\
30\end{array}$ & $\begin{array}{c}16.6 \\
816 \\
34\end{array}$ \\
\hline Lake Fehér & 27 May 2004 & 21 & 3190 & 81 & 0.1 & 210 \\
\hline Zab-szék Pan & $\begin{array}{l}1 \text { May } 2003 \\
\text { 4 Jun 2003* } \\
\text { 15 Sep 2004 } \\
\text { 17 Oct } 2004 \\
7 \text { Jul } 2005\end{array}$ & $\begin{array}{c}19 \\
21 \\
24 \\
8 \\
28\end{array}$ & $\begin{array}{c}4150 \\
13890 \\
5160 \\
6640 \\
4100\end{array}$ & $\begin{array}{c}30 \\
120 \\
11 \\
27 \\
14\end{array}$ & $\begin{array}{c}928 \\
23 \\
461 \\
2.1 \\
36\end{array}$ & $\begin{array}{l}<0.1 \\
39 \\
73 \\
58 \\
19\end{array}$ \\
\hline
\end{tabular}

tion was determined spectrofluorimetrically according to Wetzel \& Likens (1991).

The abundance and composition of the PPP was determined from fresh, unpreserved samples. Aliquots of $0.5-3 \mathrm{~mL}$ were filtered through black polycarbonate filters with $0.4 \mu \mathrm{m}$ pore-size. The filters were placed on microscopic slides and were embedded into $50 \%$ glycerol. The slides were examined with an Optiphot 2 epifluorescence microscope (Nikon, Japan) with 1000× magnification using blue-violet (BV-2A) and green (G2A) excitation light. Following the routine enumeration protocol for identifying PPP types (picocyanobacteria and picoeukaryotic algae), first the picophytoplankton cells were located under blue-violet excitation. Picoeukaryotes show deep red fluorescence under this excitation due to their chlorophyll- $a$ content. Phycoerythrinrich picocyanobacteria fluorescence is bright yellow-orange, while phycocyanin-rich picocyanobacteria show only weak red autofluorescence. By switching to green excitation for the same field, picoeukaryotic cells do not (or just very weakly) show autofluorescence. The main property distinguishing picoeukaryotic algae and phycocyanin-rich picocyanobacteria under epifluorescence microscope is the presence of phycobiliproteins in cyanobacteria, which show greatly enhanced (red) autofluorescence under green excitation (MacIsaac \& 
Tab. 3. List of primers used in this study. *: a 40 nucleotide GC-rich sequence (5'-CGC CCG CCG CGC CCC GCG CCG GTC CCG CCG CCC CCG CCC G-3') was attached to the 5' end of the primer in case of PCRs prior to DGGE.

\begin{tabular}{llll}
\hline Primer name & Sequence $\left(5^{\prime} \rightarrow 3^{\prime}\right)$ & Specificity & Reference \\
\hline 27F & AGA GTT TGA TC(A/C) TGG CTC AG & Bacteria & Lane (1991) \\
1492R & TAC GG(C/T) TAC CTT GTT ACG ACT T & universal & Lane (1991) \\
CYA106F & CGG ACG GGT GAG TAA CGC GTG A & Cyanobacteria and plastids & Nübel et al. (1997) \\
CYA359F* & GGG GAA T(C/T)T TCC GCA ATG GG & Cyanobacteria and plastids & Nübel et al. (1997) \\
CYA781R & GAC TAC (A/T)GG GGT ATC TAA TCC C(A/T)T T & $\begin{array}{l}\text { Cyanobacteria and plastids } \\
\text { cloning vector }\end{array}$ & Nübel et al. (1997) \\
M13F (-20) & GTA AAA CGA CGG CCA GT & Sambrook \& Russell (2001) \\
M13R (-24) & GGA AAC AGC TAT GAC CAT G & cloning vector & modified from Sambrook \& Russell (2001) \\
\hline
\end{tabular}

Stockner 1993). At least 20 fields were photographed with a Spot RT color camera, and the PPP were counted on these pictures to avoid fluorescence fading. In all cases, a minimum of 400 cells were counted with an error of $10 \%$ (Lund et al. 1958).

\subsection{DNA extraction and amplification}

After the concentration of $50-100 \mathrm{~mL}$ water sample by centrifugation $(5000 \mathrm{~g}, 10 \mathrm{~min})$, pellets were stored at $-20{ }^{\circ} \mathrm{C}$ for DNA extraction. First, $0.6 \mathrm{~mL}$ CLS-Y (Bio101 Systems, La Jolla, CA, USA), $300 \mathrm{mg}$ glass bead and $10 \mathrm{mg}$ of polyvinyl-polypyrrolidone were added to the samples, then the cells were disrupted in a Mixer Mill MM301 (Retsch, Haan, Germany) (1 min, $30 / \mathrm{s})$. Extraction of the genomic DNA was carried out with the Bacterial Genomic DNA Mini-Prep Kit (Vgene Biotechnology, Hangzhou, China) according to the manufacturer's protocol. Extracted genomic DNA was stored at $-20{ }^{\circ} \mathrm{C}$ for further processing.

$16 \mathrm{~S}$ rDNA amplification reactions were performed with a final volume of $50 \mu \mathrm{L}$ using approximately $2 \mu \mathrm{L}$ of purified genomic DNA, $0.2 \mathrm{mM}$ of each deoxynucleotide, $2 \mathrm{mM} \mathrm{MgCl}_{2}, 1 \mathrm{U}$ LC Taq DNA polymerase (Fermentas, Vilnius, Lithuania), 1X PCR buffer (Fermentas, Vilnius, Lithuania), $0.325 \mu \mathrm{M}$ of $27 \mathrm{~F}$ and 1492R primers (Lane 1991) (Tab. 3), and the following temperature profile: initial denaturation at $98{ }^{\circ} \mathrm{C}$ for 5 min, followed by 35 cycles of $30 \mathrm{sec}$ at $94{ }^{\circ} \mathrm{C}$ (denaturation), $30 \mathrm{sec}$ at $52{ }^{\circ} \mathrm{C}$ (annealing), $1 \mathrm{~min}$ at $72{ }^{\circ} \mathrm{C}$ (extension), and final extension at $72{ }^{\circ} \mathrm{C}$ for $10 \mathrm{~min}$. A second PCR (nested PCR) with Cyanobacteria-specific primers was performed to increase yield and achieve specificity. The composition of the nested PCR was similar to the above described protocol with the exception of the use of CYA359F (with GC clamp) and CYA781R primers (Nübel et al. 1997) for DGGE, or the CYA106F and CYA781R primers (Nübel et al. 1997) for cloning (Tab. 3), with the following cycling conditions: initial denaturation at $95{ }^{\circ} \mathrm{C}$ for $3 \mathrm{~min}$, followed by 32 cycles of $30 \mathrm{sec}$ at $94{ }^{\circ} \mathrm{C}$ (denaturation), 30 sec at $60{ }^{\circ} \mathrm{C}$ (annealing), $1 \mathrm{~min}$ at $72^{\circ} \mathrm{C}$ (extension), and final extension at $72{ }^{\circ} \mathrm{C}$ for $10 \mathrm{~min}$ (DGGE) or $30 \mathrm{~min}$ (cloning). PCR amplicons were examined by electrophoresis in an ethidium-bromide-stained $1 \%(\mathrm{w} / \mathrm{v})$ agarose gel under UV light.

Prior to cloning and sequence analysis (after reamplification of DNA from excised DGGE bands or from selected clones, see below), PCR products were purified with the PCR-M ${ }^{\mathrm{TM}}$ Clean Up System (Viogene, Sijhih, Taiwan) according to the manufacturer's instructions.

\subsection{Denaturing gradient gel electrophoresis (DGGE)}

A $1 \mathrm{~mm}$ thick $8 \%(\mathrm{w} / \mathrm{v})$ polyacrylamide gel containing a 40 to $60 \%$ gradient of denaturants $(100 \%$ is defined as $40 \%$ formamide and $7 \mathrm{M}$ urea) was used, and electrophoresis was run in $1 \mathrm{X}$ TAE buffer at $100 \mathrm{~V}$ and $60{ }^{\circ} \mathrm{C}$ for $15 \mathrm{~h}$ with an INGENYphorU-2 electrophoresis system (Ingeny International BV, Goes, The Netherlands). The gel was stained with ethidium-bromide, washed in sterile double-distilled water, and photographed under UV light. Selected bands were excised using a sterile scalpel, and the DNA was extracted with an overnight incubation in $20 \mu \mathrm{L}$ of DEPC-treated water (Carl Roth, Karlsruhe, Germany). 16S rDNA fragments recovered from DGGE bands were reamplified with the CYA359 (without GC-clamp) and CYA781R primers using the same PCR conditions were applied prior to DGGE analysis.

\subsection{Cloning}

A sample (6 June, 2003, Zab-szék Pan) with high chlorophyll- $a$ content $\left(120 \mu \mathrm{g} \mathrm{L}^{-1}\right)$ and high conductivity $\left(13890 \mu \mathrm{S} \mathrm{cm}^{-1}\right)$ was selected for cloning.

The purified PCR product was cloned using the TOPO TA Cloning ${ }^{\circledR}$ Kit containing pCR ${ }^{\circledR} 2.1-$ TOPO $^{\circledR}$ vector (Invitrogen, Carlsbad, CA, USA) according to the manufacturer's protocol. The inserted $16 \mathrm{~S}$ rDNA fragments were reamplified from the clones with the CYA106F and CYA781R primers and the clones were grouped according to their ARDRA (Amplified Ribosomal DNA Restriction Analysis) patterns generated with restriction endonucleases BsuRI and Hin6I (Fermentas). The partial $16 \mathrm{~S}$ rDNA sequence of one representative clone form each group was determined (twelve ARDRA types) using M13 primers (Tab. 3).

\subsection{Sequence analysis}

DNA fragments were sequenced with the BigDye ${ }^{\circledR}$ Terminator v3.1 Cycle Sequencing Kit (Applied Biosystems, Foster City, CA, USA) on a Model 310 Genetic Analyzer (Applied Biosystems). Sequences were analyzed using the DNA Sequencing Analysis Software v5.2 (Applied Biosystems). The chroma- 


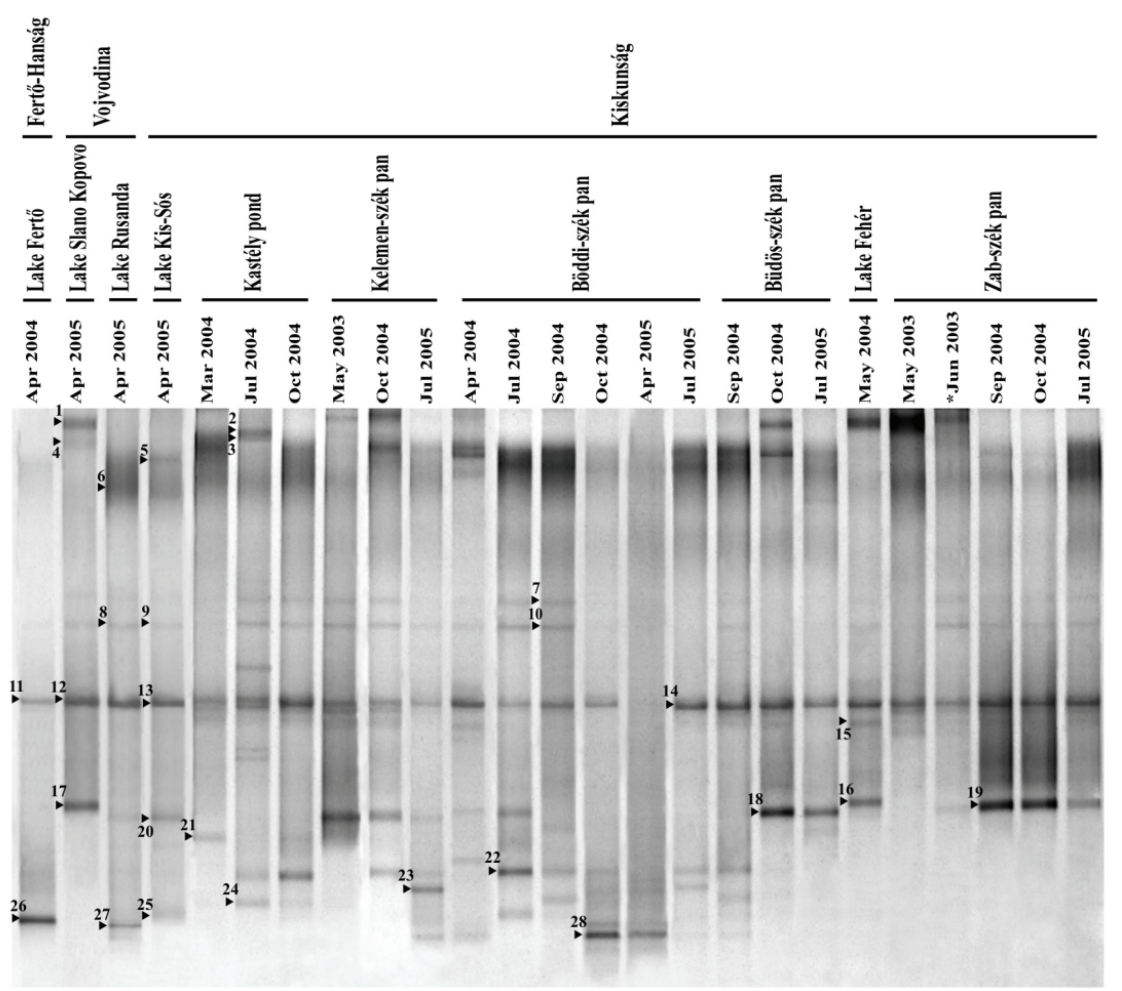

Fig. 2. DGGE profiles of DNA amplified from the investigated lakes. Triangles $(\boldsymbol{\nabla})$ indicate excised and reamplified bands. The cloned sample is indicated with an asterisk (*).

tograms were corrected manually, and primer sequences were removed using the Chromas software v1.45 (Technelysium Pty Ltd, Australia). The generated sequences were compared to the GenBank nucleotide database using the Blast program (Altschul et al. 1997). In the case of non-oxygenic phototrophic bacterial sequences, identification was enhanced with a search for type strains using EzTaxon (Chun et al. 2007). The neighbor-joining (Saitou \& Nei 1987) phylogenetic tree inferred from 301 unambiguously aligned nucleotide positions of the 16S rDNA was constructed with the MEGA4 software (Tamura et al. 2004) using ClustalW alignment (Thompson et al. 1994).

Partial 16S rDNA sequences obtained in this study have been submitted to GenBank under the following accession numbers: EU546171-EU546198 (DGGE, 28 sequences) and EU647634-EU647645 (cloning, twelve sequences).

\section{RESULTS}

\subsection{Phytoplankton biomass and PPP composition}

The studied water bodies could all be considered as brackish (hyposaline) aquatic systems, since the measured conductivity values amounted to $1.0-9.5 \%$ salinity, and most of these turbid, saline lakes had a relatively high chlorophyll- $a$ content (Tab. 2), indicating a high trophic state based on the OECD classification system (OECD 1982). In Lake Fertö, the chlorophyll- $a$ concentration was $31 \mu \mathrm{g} \mathrm{L}^{-1}$, in accordance with its known meso-eutrophic state. The saline lakes of Vojvodina (Lake Slano Kopovo and Lake Rusanda) and one lake from the Kiskunság Region (Lake Kis-Sós) had relatively low chlorophyll- $a$ concentration at sampling (6.0, 2.0 and $3.0 \mu \mathrm{g} \mathrm{L}^{-1}$, respectively). Kastély Pond, Böddiszék Pan, Lake Fehér and Zab-szék Pan had maximum values of chlorophyll- $a$ concentration exceeding the 75 $\mu \mathrm{g} \mathrm{L}{ }^{-1}$ threshold defined for the hypertrophic state. In the samples taken from Kelemen-szék and Büdös-szék Pans, this value was lower (7.6-24 and 11-44 $\mu \mathrm{g} \mathrm{L}^{-1}$, respectively).

The PPP was dominated by eukaryotic picoalgae and phycocyanin-rich picocyanobacteria (Tab. 2). Phycoerythrin-rich picocyanobacteria were not detected in our samples. PPP density varied from $7.8 \times 10^{4}$ to $1.82 \times$ $10^{7}$ cells $\mathrm{mL}^{-1}$, the highest cell numbers were measured in Böddi-szék Pan. The abundance of picocyanobacteria varied from $0.1 \times 10^{4}$ to $1.78 \times 10^{7}$ cells $\mathrm{mL}^{-1}$, the maximum value was measured in Böddi-szék Pan in September, 2004. The abundance of picoeukaryotes varied from $<0.1 \times 10^{4}$ to $8.16 \times 10^{6}$ cells $\mathrm{mL}^{-1}$, the maximum value was measured in Büdös-szék Pan in October, 2004.

\subsection{Molecular characterization of the PPP community}

The DGGE analysis revealed a variable pattern with notable differences among the samples (Fig. 2). Sequence analysis of the 28 distinct DGGE bands showed that all reamplified sequences were related to either cyanobacterial or eukaryotic plastid 16S rDNA (Fig. 3). 


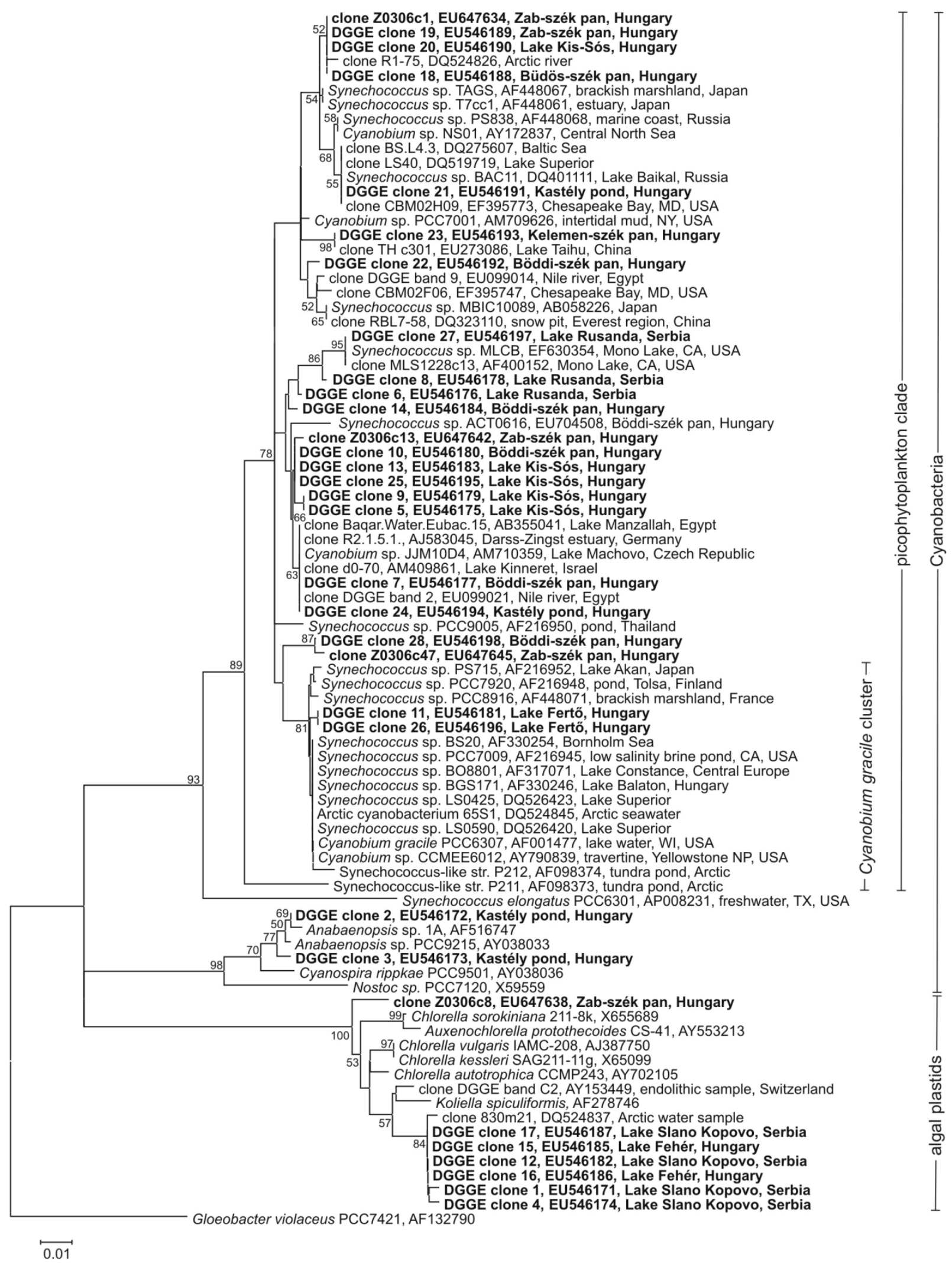

Fig. 3. Phylogenetic position to their closest relatives of the sequences related to oxygenic phototrophs determined in this study. Bootstrap values $<50 \%$ are not shown. Bar indicates 0.01 nucleotide substitution per site. Isolation details are also shown for environmental clones and picocyanobacterial isolates. Sequences determined in this study appear in bold letters. 
Tab. 4. Phylospecies identification results based on cloning the water sample from Zab-szék Pan taken on 6 June, 2003. ${ }^{\mathrm{T}}$ type strain.

\begin{tabular}{|c|c|c|c|}
\hline $\begin{array}{l}\text { Sequenced } \\
\text { clone }\end{array}$ & $\begin{array}{l}\text { Percentage of } \\
\text { clone library }\end{array}$ & $\begin{array}{l}\text { Sequence } \\
\text { similarity }\end{array}$ & Closest relative \\
\hline Z0306c1 & $11.8 \%$ & $99.0 \%$ & clone LS40 (Lake Superior) \\
\hline Z0306c3 & $2.6 \%$ & $88.2 \%$ & Opitutus terrae $\mathrm{PB} 90-1^{\mathrm{T}}$ \\
\hline Z0306c5 & $6.6 \%$ & $78.8 \%$ & Sphingomonas koreensis KCТC $2882^{\mathrm{T}}$ \\
\hline $\mathrm{Z} 0306 \mathrm{c} 7$ & $2.6 \%$ & $90.6 \%$ & Opitutus terrae $\mathrm{PB} 90-1^{\mathrm{T}}$ \\
\hline Z0306c8 & $13.2 \%$ & $94.7 \%$ & Chlorella kessleri SAG211-11 $\mathrm{g}^{\mathrm{T}}$, plastid \\
\hline Z0306c9 & $15.8 \%$ & $90.9 \%$ & Opitutus terrae $\mathrm{PB} 90-1^{\mathrm{T}}$ \\
\hline Z0306c11 & $15.8 \%$ & $87.9 \%$ & Verrucomicrobium spinosum DSM4136 \\
\hline $\mathrm{Z} 0306 \mathrm{c} 13$ & $18.4 \%$ & $99.2 \%$ & Cyanobium sp. JJM10D4 \\
\hline Z0306c16 & $4.0 \%$ & $90.3 \%$ & Opitutus terrae $\mathrm{PB} 90-1^{\mathrm{T}}$ \\
\hline Z0306c17 & $5.3 \%$ & $89.7 \%$ & Opitutus terrae $\mathrm{PB} 90-1^{\mathrm{T}}$ \\
\hline Z0306c18 & $2.6 \%$ & $86.1 \%$ & Rubritalea squalenifaciens DSM18772 ${ }^{\mathrm{T}}$ \\
\hline $\mathrm{Z} 0306 \mathrm{c} 47$ & $1.3 \%$ & $97.8 \%$ & Synechococcus sp. PCC9005 \\
\hline
\end{tabular}

The twelve different ARDRA types resulted from the restriction endonuclease screening of the Zab-szék Pan clone library consisting of 76 clones. Sequence analysis of the representative clones (Fig. 3, Tab. 4) showed that $44.7 \%$ of the clone library was related to sequences derived from oxygenic phototrophs (31.5\% to picocyanobacteria and $13.2 \%$ to plastid sequences). The remaining sequences $(55.3 \%$ of total clones) showed low similarity values to the bacterial phylum Verrucomicrobia.

PPP sequences from the Zab-szék Pan clone library belonged to three distinct branches within the picophytoplankton clade of Cyanobacteria (sensu Urbach et al. 1998). Picocyanobacterial sequences from the other samples also had some genetic diversity (Lake Rusanda, 23 April, 2005: 98.0-99.0\%; Lake Kis-Sós, 23 April, 2005: 97.6-100\% pairwise similarities) or were almost or completely identical (Böddi-szék Pan, 3 September, 2004: 99.7\%; Lake Slano Kopovo, 23 April, 2005: 99.3$100 \%$ pairwise similarities; sequences derived from Lake Fehér and Lake Fertő were identical, respectively). When samples of different time periods of the same lake were compared, picocyanobacteria could be affiliated to at least two different phylogenetic groups (Fig. 3). Two clones (DGGE clone 2 and 3 ) originating from the same sample (Kastély Pond, 4 July, 2004) were related to the non-PPP cyanobacterial genus Anabaenopsis (Nostocales), both sharing $>99 \%$ similarity with the PCC 9215 strain. The presence of this genus in the sample was also observed during microscopic investigation.

Sequences related to eukaryotic algal plastids formed two separate groups, both within the family of Trebouxiophyceae, closely related to the genera Chlorella and Koliella.

Nonetheless, our molecular identification was based on a relatively short fragment of the $16 \mathrm{~S}$ rDNA, previously undiscovered members of PPP were identified in the investigated soda lakes (e.g., the Trebouxiophycean clone Z0306c8 or the picocyanobacterial group formed by clones Z0306c47 and DGGE clone 28 in Fig. 3).

\section{DISCUSSION}

\subsection{Occurrence of PPP in the alkaline lakes of the Carpathian Basin}

The investigated water bodies were highly productive and characterized as eu- or hypertrophic, as it was confirmed in most cases with our punctual sampling. The highest chlorophyll- $a$ concentration was detected in two soda lakes of the Kiskunság Region, in Böddi-szék and in Zab-szék Pans $\left(120 \mu \mathrm{g} \mathrm{L}^{-1}\right)$. But the maximum measured chlorophyll- $a$ concentration was much higher in the lakes of this region: $300 \mu \mathrm{g} \mathrm{L}{ }^{-1}$ in Kelemen-szék Pan and $797 \mu \mathrm{g} \mathrm{L}^{-1}$ in Büdös-szék Pan (Somogyi et al. 2009).

A high number of PPP cells was detected in the investigated turbid, alkaline lakes, ranging from $10^{5}$ to $10^{7}$ cells $\mathrm{mL}^{-1}$. In extremely productive periods, the abundance of picoeukaryotic and picocyanobacterial cells could be even higher in the lakes of the Kiskunság Region. Maximum observed values were $1.08 \times 10^{8}$ cells $\mathrm{mL}^{-1}$ (Somogyi et al. 2009) and $1.03 \times 10^{8}$ cells $\mathrm{mL}^{-1}$ (Vörös et al. 2005), respectively. These values were the highest ever reported in the literature (Sarmento et al. 2008; Somogyi et al. 2009). The extremely high cell abundance of planktonic phototrophs is supposedly related to the fact that there is no nutrient limitation in these water bodies due to the high nitrogenand phosphorous-load from wintering and migrating aquatic birds (Boros et al. 2008). The increased surfaceto-volume ratio of cells that is hypothesized to be affiliated with better light utilization (Agustí 1991) and nutrient uptake efficiency (Reynolds 2006) could account for the selective advantage of this pico-sized fraction in such turbid, light limited environments with high nutrient supply.

Picoeukaryotic algae and phycocyanin-rich picocyanobacteria constituted the PPP community of the investigated saline lakes, but picocyanobacteria with phycoerythrin pigment dominance were absent from all samples, in line with previous studies (Vörös \& V.- 
Balogh 2003; Vörös et al. 2005; Vörös et al. 2008; Somogyi et al. 2009). High concentration of dissolved and particulate matter led to a 'red shift' in the underwater light spectrum providing favorable conditions for phycocyanin-rich picocyanobacteria (Callieri et al. 1996; Vörös et al. 1998; Stomp et al. 2007).

Temporal changes in the PPP community were detected through the changes in the abundance of picocyanobacteria and picoeukaryotic algae or through the presence or absence of bands in DGGE profiles supported with the sequence analysis of the DNA fragments reamplified from these bands. The alteration of the photoautotrophic community structure was confirmed at most sampling sites where at least two samples were taken. Although our results did not allow to draw conclusions regarding the seasonal dynamics of PPP in these saline lakes due to the limited number of samples per year, previous investigations demonstrated the dominance of picocyanobacteria in the summer and picoeukaryotic algae in the winter and spring (Vörös et al. 2005; Vörös et al. 2008; Somogyi et al. 2009), similarly to other lakes of the temperate zone (Weisse 1993; Callieri 2008). A recent study (Somogyi et al. 2009) focusing on the saline pans of the Kiskunság Region revealed that the combination of changes in light and temperature controlled the in situ dynamics of PPP in these turbid environments. Ecophysiological investigation of two isolated strains confirmed that at low temperatures, the picoeukaryotic alga, while at temperatures higher than $17{ }^{\circ} \mathrm{C}$, the picocyanobacterial strain could better utilize low intensity light (Somogyi et al. 2009). This could be accounted for the phenomenon that the dominance of eukaryotes over cyanobacteria in the PPP was pronounced in cold water periods.

It is also noteworthy that, in parallel with the changes in the PPP community, in some cases there were rapid shifts in conductivity within a relatively short period of time due to evaporative desiccation. Increasing salinity leads to the reduction of planktonic phylum- to genus-level microbial diversity at high salinities (Pedrós-Alió et al. 2000, Benlloch et al. 2002), although disturbances (such as extreme spatio-temporal variations in salinity) have been proposed to promote microbial diversity (Walsh et al. 2005). Our current knowledge on the impact of salinity on PPP diversity is limited. Jing et al. (2009) studied marine Synechococcus communities in subtropical coastal waters, and revealed that salinity and water turbidity could be the possible controlling factors of Synechococcus population diversity. Therefore, investigating the effect of rapidly changing salinity on PPP diversity in these saline lakes could be an interesting issue in the future.

\subsection{Phylogenetic position of PPP in the alkaline lakes of the Carpathian Basin}

The retrieved PPP sequences from the investigated saline lakes were related to the picophytoplankton clade of Cyanobacteria (sensu Urbach et al. 1998) or to Chlorella species within the family Trebouxiophyceae (Chlorophyta). These are the most abundant members of the pro- and eukaryotic PPP in freshwater ecosystems (Callieri 2008). There is only limited information available regarding the taxonomic position of PPP inhabiting the turbid, alkaline lakes of the Carpathian Basin. Somogyi et al. (2009) isolated and identified one picoeukaryotic and one picocyanobacterial strain from Böddi-szék Pan (Kiskunság Region). On the basis of the partial sequence analysis of the $16 \mathrm{~S}$ rDNA, the picocyanobacterial strain (ACT0616) was identified as a nonmarine member of the picophytoplankton clade, sharing $98.7 \%$ pairwise similarity with our DGGE clone 7 (Fig. 3). On the basis of the partial analysis of the $18 \mathrm{~S}$ rDNA, the picoeukaryotic strain was distantly related to other algal isolates, and therefore this strain was proposed to be a member of a candidate new chlorophyte genus (B. Somogyi, unpublished results). Considering the selectivity of classical isolation techniques (Ernst 1991; Ernst et al. 2003), the composition of the PPP could not be defined with the identification of a few isolated strains, therefore this can be ragarded as the first consistent survey dealing with the taxonomic characterization of the PPP community composition in the turbid, alkaline water bodies of the Carpathian Basin.

A relatively high genetic diversity was found among the sequences determined in this study, especially in case of picocyanobacteria. We suppose that all picocyanobacterial sequences recovered from these lakes could be derived from phycocyanin-rich cells, since no phycoerythrin-rich cells were observed during the microscopic investigations.

Picocyanobacterial sequences from Lake Fertő belonged to the Cyanobium gracile cluster (sensu Ernst et al. 2003), a group containing both phycoerythrin- and phycocyanin-rich isolates from different habitats and geographical locations. PPP sequences from the Kiskunság soda lakes had high genetic variance and did not diverge from the sequences of the Vojvodina Region: no geographical separation was observed in the phylogenetic tree. The closest relatives of almost all picocyanobacterial sequences identified in this study were recovered from distant geographical regions and/or from different habitats (lake or river, brackish or marine environment).

The retrieved sequences were widely distributed within the picophytoplankton clade; in other words, there seems to be no correlation between the 'saline' ecotypes of picocyanobacteria and their phylogenetic position, since strains or clones derived from brackish and marine environments clustered with freshwater sequences (Fig. 3, Crosbie et al. 2003; Budinoff \& Hollibaugh 2007; Sánchez-Baracaldo et al. 2008). Recent molecular investigations did not only provide information about the widespread geographical distribution of many genotypes, but also revealed that freshwa- 
ter/terrestrial picocyanobacterial communities shared much greater diversity than their marine counterparts (this study; Crosbie et al. 2003; Ivanikova et al. 2007; Sánchez-Baracaldo et al. 2008). This could be explained with a more rapid speciation induced by geographical barriers or with the long evolutionary history of freshwater picocyanobacteria (Sánchez-Baracaldo et al. 2008). The latter was supported with a study combining phylogenetic analysis of slowly evolving genes and morphological characters (Sánchez-Baracaldo et al. 2005), which demonstrated the probable terrestrial/freshwater origin of Cyanobacteria coupled with small cell diameter and free-living planktonic habit (a typical Synechococcus) shared in these ancient lineages. The potential to colonize marine environments, as well as the acquisition of derived traits (complex morphology, thermophily, motility, etc.) were gained later in the independent cyanobacterial lineages.

Although most nonmarine picocyanobacterial clusters appear to be cosmopolitan, intensive investigations on PPP communities gave rise to new groups with the restriction of some genotypes to a particular ecosystem or geographical location (Crosbie et al. 2003; Ivanikova et al. 2007; Sánchez-Baracaldo et al. 2008). The adaptive potential of PPP to extreme environmental conditions (e.g., in our case high $\mathrm{pH}$, salinity and light limitation) also illustrates the evolutionary success of these small-sized phototrophs.

\subsection{Remarks on the biases associated with the methods applied in this study}

With regards to the DGGE technique, we noticed that identical sequences could generate multiple bands (e.g., DGGE clones from Lake Fertö), and sequences reamplified from excised bands located in the same position of the gel could be different (e.g., DGGE clones 11-14). One possible explanation for obtaining identical sequences from different bands in the same lane is the occurrence of both homoduplex and heteroduplex molecules (Ferris \& Ward 1997). The co-migration of different fragments was also reported (Sekiguchi et al. 2001), but other deviations may also appear and influence the results (Kisand \& Wikner 2003; Nikolausz et al. 2005).

The extent to which the observed fine-scale variation of $16 \mathrm{~S}$ rDNA sequences could be related to artefacts (e.g., Taq errors, heteroduplex molecules), heterogeneity among paralogous operons or to the co-existence of closely-related taxa is also uncertain (Acinas et al. 2004).

A notable portion of our clone sequences were related to Verrucomicrobia. The members of this phylum are well known inhabitants of eutrophic or extreme environments such as soda lakes (Schlesner et al. 2006). Interestingly, sequences related to microorganisms other than oxygenic phototrophs were not retrieved by DGGE. This could be the result of the different speci- ficity of the forward primers applied for cloning (CYA106F) and for DGGE (CYA359F) that resulted in the disparate amplification of taxa (Sipos et al. 2007). Similar problems of unspecific amplification associated with the primers applied in this study for cloning were also reported (Katano et al. 2001; Ivanikova et al. 2007).

These phenomena draw attention to the biases associated with molecular methods that use complex PCR products and to question the application of DGGE pattern comparison or pattern analysis without sequencing.

\section{CONCLUSIONS}

This study characterized PPP communities of ten soda lakes located in the Carpathian Basin. In some of these water bodies, their abundance could reach the highest values ever reported in literature with exclusive dominance of PPP in total primary production. The contribution of picoeukaryotes to the total PPP was highly variable among lakes, ranging from 0 to $100 \%$. The development of extreme hypertrophy was related to the high nutrient concentration.

Despite the hyposaline character of these lakes, the prokaryotic members of the PPP were phylogenetically related to the nonmarine Synechococcus/Cyanobium group within the picophytoplankton clade, while the eukaryotic members were affiliated to Chlorella isolates. Most of our sequences were related to clones or strains originating from distant geographical locations that supported the widespread dispersal of some groups of PPP. The relatively high genetic diversity of PPP in such extreme environments with rapidly changing physicochemical parameters (especially in the case of picocyanobacteria) demonstrates the adaptive potential and confirms the evolutionary success of these smallsized phototrophs.

\section{ACKNOWLEDGEMENTS}

This work was supported by the Hungarian Scientific Research Fund (OTKA K 73369). The authors wish to thank for correction of English grammar to R. Sipos.

\section{REFERENCES}

Acinas, S.G., V. Klepac-Ceraj, D.E. Hunt, C. Pharino, I. Ceraj, D.L. Distel \& M.F. Polz. 2004. Fine-scale phylogenetic architecture of a complex bacterial community. Nature, 430: 551-554.

Agawin, N.S.R., C.M. Duarte \& S. Agustí. 2000. Nutrient and temperature control of the contribution of picoplankton to phytoplankton biomass and production. Limnol. Oceanogr., 45: 591-600.

Agustí, S. 1991. Allometric scaling of light absorption and scattering by phytoplankton cells. Can. J. Fish. Aquat. Sci., 48: 763-767.

Altschul, S.F., T.L. Madden, A.A. Schäffer, J. Zhang, Z. Zhang, W. Miller \& D.J. Lipman. 1997. Gapped BLAST and PSI-BLAST: a new generation of protein database search programs. Nucleic Acids Res., 25: 3389-3402.

Bell, T. \& J. Kalff. 2001. The contribution of picophytoplankton in marine and freshwater systems of different 
trophic status and depth. Limnol. Oceanogr., 46: 12431248.

Benlloch, S., A. López-López, E.O. Casamayor \& 9 others. 2002. Prokaryotic genetic diversity throughout the salinity gradient of a coastal solar saltern. Environ. Microbiol., 4: 349-360.

Boros, E., T. Nagy, C. Pigniczki, L. Kotymán, K. V.-Balogh \& L. Vörös. 2008. The effect of aquatic birds on the nutrient load and water quality of soda pans in Hungary. Acta Zool. Hung., 54 (S1): 207-224.

Budinoff, C.R. \& J.T. Hollibaugh. 2007. Ecophysiology of a Mono Lake picocyanobacterium. Limnol. Oceanogr., 52: 2484-2495.

Callieri, C. 2008. Picophytoplankton in freshwater ecosystems: the importance of small-sized phototrophs. Freshwater Reviews, 1: 1-28.

Callieri, C., E. Amicucci, R. Bertoni \& L. Vörös. 1996. Fluorometric characterization of two picocyanobacteria strains from lakes of different underwater light quality. Int. Revue ges. Hydrobiol., 81: 13-23.

Carrick, H.J., C.L. Schelske. 1997. Have we overlooked the importance of small phytoplankton in productive waters? Limnol. Oceanogr., 42: 1613-1621.

Chisholm, S.W., R.J. Olson, E.R. Zettler, R. Goericke, J.B. Waterbury \& N.A. Welschmeyer. 1988. A novel free-living prochlorophyte abundant in the oceanic euphotic zone. Nature, 334: 340-343.

Chun, J., J-H. Lee, Y. Jung, M. Kim, S. Kim, B.K. Kim \& YW. Lim. 2007. EzTaxon: a web-based tool for the identification of prokaryotes based on $16 \mathrm{~S}$ ribosomal RNA gene sequences. Int. J. Syst. Evol. Microbiol., 57: 2259-2261.

Cole, J.R., B. Chai, T.L. Marsh \& 8 others. 2003. The Ribosomal Database Project (RDP-II): previewing a new autoaligner that allows regular updates and the new prokaryotic taxonomy. Nucleic Acids Res., 31: 442-443.

Crosbie, N.D., M. Pöckl \& T. Weisse. 2003. Dispersal and phylogenetic diversity of nonmarine picocyanobacteria, inferred from 16S rRNA gene and cpcBA-intergenic spacer sequence analyses. Appl. Environ. Microbiol., 69: 5716-5721.

Dokulil, M. \& J. Padisák. 1994. Long-term compositional response of phytoplankton in a shallow, turbid environment, Neusiedlersee, Austria/Hungary. Hydrobiologia, 275-276: 125-137.

Dorigo, U., L. Volatier \& J-F. Humbert. 2005. Molecular approaches to the assessment of biodiversity in aquatic microbial communities. Water Res., 39: 2207-2218.

Ernst, A. 1991. Cyanobacterial picoplankton from Lake Constance. I. Isolation by fluorescence characteristics. $J$. Plankton Res., 13: 1307-1312.

Ernst, A., S. Becker, U.I. Wollenzien \& C. Postius. 2003. Ecosystem-dependent adaptive radiations of picocyanobacteria inferred from 16S rRNA and ITS-1 sequence analysis. Microbiol. (UK), 149: 217-228.

Ferris, M.J. \& D.M. Ward. 1997. Seasonal distributions of dominant $16 \mathrm{~S}$ rRNA-defined populations in a hot spring microbial mat examined by denaturing gradient del electrophoresis. Appl. Environ. Microbiol., 63: 1375-1381.

Fuller, N.J., C. Campbell, D.J. Allen, F.D. Pitt, K. Zwirglmaier, F. Le Gall, D. Vaulot \& D.J. Scanlan. 2006. Analysis of photosynthetic picoeukaryote diversity at open ocean sites in the Arabian Sea using a PCR biased towards marine algal plastids. Aquat. Microb. Ecol., 43: 79-93.

Henley, W.J., J.L. Hironaka, L. Guillou, M.A. Buchheim, J.A. Buchheim, M.W. Fawley \& K.P. Fawley 2004. Phylogenetic analysis of the 'Nannochloris-like' algae and diagnoses of Picochlorum oklahomensis gen. et sp. nov. (Trebouxiophyceae, Chlorophyta). Phycologia, 43: 641-652.

Honda, D., A. Yokota \& J. Sugiyama. 1999. Detection of seven major evolutionary lineages in cyanobacteria based on the $16 \mathrm{~S}$ rRNS gene sequence analysis with new se- quences of five marine Synechococcus strains. J. Mol. Evol., 48: 723-739.

Huss, V.A.R., C. Frank, E.C. Hartmann, M. Hirmer, A. Klocoucek, B.M. Seidel, P. Wenzeler \& E. Kessler. 1999. Biochemical taxonomy and molecular phylogeny of the genus Chlorella sensu lato (Chlorophyta). J. Phycol., 35: $587-598$.

Ivanikova, N.V., L.C. Popels, M.L. McKay \& G.S. Bullerjahn. 2007. Lake Superior supports novel clusters of cyanobacterial picoplankton. Appl. Environ. Microbiol., 73: 40554065.

Jing H.M., R. Zhang, S.B. Pointing, H.B. Liu \& P. Qian. 2009. Genetic diversity and temporal variation of the marine Synechococcus community in the subtropical coastal waters of Hong Kong. Can. J. Microbiol., 55: 311-318.

Johnson, P.W. \& J.M. Sieburth. 1979. Chroococcoid cyanobacteria in the sea: A ubiquitous and diverse phototrophic biomass. Limnol. Oceanogr., 24: 928-935.

Katano, T., M. Fukui \& Y. Watanabe. 2001. Identification of cultured and uncultured picocyanobacteria from a mesotrophic freshwater lake based on the partial sequences of 16S rDNA. Limnology, 2: 213-218.

Kisand, V. \& J. Wikner. 2003. Limited resolution of $16 \mathrm{~S}$ rDNA DGGE caused by melting properties and closely related DNA sequences. J. Microbiol. Meth., 54: 183-191.

Lane, D.J. 1991. 16S/23S rRNA sequencing. In: Stackebrandt, E. \& M. Goodfellow (Eds), Nucleic acid techniques in bacterial systematics. John Wiley and Sons, New York, pp. 115-175.

Li, W.K.W. \& A.M. Wood. 1988. Vertical distribution of North Atlantic ultraphytoplankton: Analysis by flow cytometry and epifluorescence microscopy. Deep-Sea Res., 35: 1615-1638.

Lund, J.W.G., C. Kipling \& E.D. Le Cren. 1958. The inverted microscope method of estimating algal numbers and the statistical basis of estimations by counting. Hydrobiologia, 11: $143-170$.

MacIsaac E.A. \& J.G. Stockner. 1993. Enumeration of phototrophic picoplankton by autofluorescence microscopy. In: Kemp, P.F, B.F. Sherr, E.B. Sherr \& J.J. Cole (Eds), The handbook of methods in aquatic microbial ecology. CRC Press, Boca Raton, FL, pp. 187-197.

Moon-van der Staay, S.Y., R. De Wachter \& D. Vaulot. 2001. Oceanic 18S rDNA sequences from picoplankton reveal unsuspected eukaryotic diversity. Nature, 409: 607-610.

Nikolausz, M., R. Sipos, S. Révész, A. Székely \& K. Márialigeti. 2005. Observation of bias associated with re-amplification of DNA isolated from denaturing gradient gels. FEMS Microbiol. Lett., 244: 385-390.

Nübel, U., F. Garcia-Pichel \& G. Muyzer. 1997. PCR primers to amplify $16 \mathrm{~S}$ rRNA genes from Cyanobacteria. Appl. Environ. Microbiol., 63: 3327-3332.

OECD. 1982. Eutrophication of waters. Monitoring, assessment and control. OECD, Paris: $154 \mathrm{pp}$.

Olson, R.J., S.W. Chisholm, E.R. Zettler \& E.V. Armbrust. 1990. Pigments, size and distribution of Synechococcus in the North Atlantic and Pacific Oceans. Limnol. Oceanogr., 35: 45-58.

Padisák, J. \& M. Dokulil. 1994. Meroplankton dynamics in a saline, turbulent, turbid shallow lake (Neusiedlersee, Austria and Hungary). Hydrobiologia, 289: 23-42.

Pedrós-Alió, C., J.I. Calderón-Paz, M.H. MacLean, G. Medina, C. Marrasé, J.M. Gasol, N. Guixa-Boixereu. 2000. The microbial food web along salinity gradients. FEMS Microbiol. Ecol., 32: 143-155.

Reynolds, C.S. 2006. The ecology of phytoplankton. Cambridge University Press, Cambridge.

Rippka, R., T. Coursin, W.R. Hess, C. Lichtlé, D.J. Scanlan, K. Palinska, I. Iteman, F. Partensky, J. Houmard, \& M. Herdman. 2000. Prochlorococcus marinus Chisholm et al. 1992, subsp. nov. pastoris, strain PCC 9511, the first ax- 
enic chlorophyll $a_{2} / b_{2}$-containing cyanobacterium (Oxyphotobacteria). Int. J. Syst. Evol. Microbiol., 50: 18331847.

Robertson, B.R., N. Tezuka, \& M.M. Watanabe. 2001. Phylogenetic analyses of Synechococcus strains (cyanobacteria) using sequences of $16 \mathrm{~S}$ rDNA and part of the phycocyanin operon reveal multiple evolutionary lines and reflect phycobilin content. Int. J. Syst. Evol. Microbiol., 51: 861-871.

Saitou, N. \& M. Nei. 1987. The neighbor-joining method: a new method for reconstructing phylogenetic trees. Mol. Biol. Evol., 4: 406-425.

Sambrook, J. \& D.W. Russell. 2001. Molecular cloning: a laboratory manual. Chapter 8: In vitro amplification of DNA by the polymerase chain reaction, 3rd Ed. Cold Spring Harbor Laboratory Press, New York, 8.115.

Sánchez-Baracaldo, P., P.K. Hayes \& C.E. Blank. 2005. Morphological and habitat evolution in the Cyanobacteria using a compartmentalization approach. Geobiology, 3: 145165.

Sánchez-Baracaldo, P., B.A. Handley \& P.K. Hayes. 2008. Picocyanobacterial community structure of freshwater lakes and the Baltic Sea revealed by phylogenetic analyses and clade-specific quatitative PCR. Microbiol. (UK), 154: 3347-3357.

Sarmento, H., F. Unrein, M. Isumbisho, S. Stenuite, J.M. Gasol \& J-P. Descy. 2008. Abundance and distribution of picoplankton in tropical, oligotrophic Lake Kivu, eastern Africa. Freshwat. Biol., 53: 756-771.

Schlesner, H., C. Jenkins \& J.T. Staley. 2006. The phylum Verrucomicrobia: A phylogenetically heterogeneous bacterial group. In: Dworkin, M, S. Falkow, E. Rosenberg, KH. Schleifer \& E. Stackebrandt (Eds), The Prokaryotes. Vol. 7. Springer Science+Business Media, LLC, New York: 881-896.

Schmidt, A. 2003. Comparing water chemical investigations of sodic ponds in the Kiskunság National Park (KNP II). Természetvédelmi Közlemények, 10: 153-162. (in Hungarian with English summary)

Schmidt, A. \& G. Fehér. 2001. Water chemical and algological investigations of sodic ponds in the Kiskunság National Park (KNP II). Hidrológiai Közlöny, 81: 455-456. (in Hungarian with English summary)

Sekiguchi, H., N. Tomioka, T. Nakahara \& H. Uchiyama. 2001. A single band does not always represent single bacterial strains in denaturing gradient gel electrophoresis. Biotechnol. Lett., 23: 1205-1208.

Sipos, R., A.J. Székely, M. Palatinszky, S. Révész, K. Márialigeti \& M. Nikolausz. 2007. Effect of primer mismatch, annealing temperature and PCR cycle number on 16S rRNA gene-targeting bacterial community analysis. FEMS Microbiol. Ecol., 60: 341-350.

Somogyi, B., T. Felföldi, J. Vanyovszky, Á. Ágyi, K. Márialigeti \& L. Vörös. (2009). Winter bloom of picoeukaryotes in extremely shallow turbid soda lakes. Aquat. Ecol:: (in press).

Søndergaard, M. 1991. Phototrophic picoplankton in temperate lakes: Seasonal abundance and importance along a trophic gradient. Int. Revue ges. Hydrobiol., 76: 505-522.
Stockner, J.G. 1988. Photoautotrophic picoplankton: An overview from marine and freshwater ecosystems. Limnol. Oceanogr., 33: 765-775.

Stockner, J.G. \& K.S. Shortreed. 1991. Autotrophic picoplankton: Community composition, abundance and distribution across a gradient of oligotrophic British-Columbia and Yukon-Territory lakes. Int. Revue ges. Hydrobiol., 76: 581-601.

Stomp, M., J. Huisman, L.J. Stal \& H.C.P. Matthijs. 2007. Colorful niches of phototrophic microorganisms shaped by vibrations of the water molecule. The ISME Journal, 1: 271-282.

Tamura, K., J. Dudley, M. Nei \& S. Kumar. 2007. MEGA4: Molecular Evolutionary Genetics Analysis (MEGA) software version 4.0. Mol. Biol. Evol., 24: 1596-1599.

Thompson, J.D., D.G. Higgins \& T.J. Gibson. 1994. Clustal $\mathrm{W}$ : improving the sensitivity of progressive multiple sequence alignment through sequence weighting, positionspecific gap penalties and weight matrix choice. Nucleic Acids Res., 22: 4673-4680.

Turner, S., K.M. Pryer, V.P.W. Miao \& J.D. Palmer. 1999. Investigating deep phylogenetic relationships among cyanobacteria and plastids by small subunit rRNA sequence analysis. J. Eukaryot. Microbiol., 46: 327-338.

Urbach, E., D.J. Scanlan, D.L. Distel, J.B. Waterbury \& S.W. Chisholm. 1998. Rapid diversification of marine picophytoplankton with dissimilar light-harvesting structures inferred from sequences of Prochlorococcus and Synechococcus (Cyanobacteria). J. Mol. Evol., 46: 188-201.

Vörös, L. \& K. V.-Balogh. 2003. Photoautotrophic picoplankton of the natron lakes in the Danube-Tisza Interfluve. Természetvédelmi Közlemények, 10: 185-189. (in Hungarian with English summary)

Vörös, L., B. Somogyi \& E. Boros. 2008. Birds cause net heterotrophy in shallow lakes. Acta Zool. Hung., 54 (S1): 2334.

Vörös, L., K. V.-Balogh \& E. Boros. 2005. Picoplankton predominance in soda lakes. Hidrológiai Közlöny, 85: 166168. (in Hungarian with English summary)

Vörös, L., C. Callieri, K. V-Balogh \& R. Bertoni. 1998. Freshwater picocyanobacteria along a trophic gradient and light quality range. Hydrobiologia, 369/370: 117-125.

Vörös, L., E. Boros, A. Schmidt, K. V.-Balogh, B. Németh, B. Somogyi \& A. Mózes 2006. Physical and chemical environment of phytoplankton in soda pans having white coloured water. Hidrológiai Közlöny, 86: 139-141. (in Hungarian with English summary)

Walsh, D.A., R.T. Papke \& W.F. Doolittle. 2005. Archaeal diversity along a soil salinity gradient prone to disturbance. Environ. Microbiol., 7: 1655-1666.

Waterbury, J.B., S.W. Watson, R.R.L. Guillard \& L.E. Brand. 1979. Widespread occurrence of a unicellular, marine, planktonic cyanobacterium. Nature, 277: 293-294.

Weisse, T. 1993. Dynamics of autotrophic picoplankton in marine and freshwater ecosystems. In: J.G. Jones (Ed.), Advances in microbial ecology. Vol. 13. Plenum Press, New York, pp. 327-370.

Wetzel, R.G. \& G.E. Likens. 1991. Limnological Analyses. 2nd Ed. Springer-Verlag, New York. 